\title{
Szabálytalan alakú égitestek térképi referencia-rendszereinek kidolgozása
}

\author{
Takáts Tünde - Kerkovits Krisztián
}

DOI: $10.30921 / G K .72 .2020 .2 .3$

Absztrakt: Az üreszközök gyors fejlödésének köszönhetöen egyre jobban megismerjük a minket körülvevö világot. A kisbolygók és az üstökösök felfedezése során azt tapasztaljuk, hogy ezek alakja nem mindig közelíthetố az általunk megszokott gömbformával. Az ilyen szabálytalan alakú égitestekrôl készült térképeket nehéz áttekinteni, ezért sokszor szoktak a 3D-s modelljükröl perspektiv ábrákat mellékelni hozzájuk, hogy jobban el tudjuk képzelni, miként is van a valóságban. Ebben a tanulmányban egy érdekes formájú üstökös térképezési lehetôségével foglalkozunk. Bemutatjuk, hogy lehetséges olyan térképet készíteni, amelyrôl meghatározhatók (koordinátákkal leírhatók) a felszín pontjai, sőt még a vizsgált égitest alakját is szemlélteti.

Abstract: The continuous development of space technology allows us to get to know more and more celestial bodies, which have diverse shapes. Some of them have irregular bodies, which cannot be described by a reference surface like a sphere or an ellipsoid of revolution. In this study, a method is introduced to map irregular objects. This process was tested on the 3D model of the comet 67P/Churyumov-Gerasimenko. For the definition of the reference surface, a central point was obtained, from which all points of the surface are visible. Then, the shape of the comet was approximated by an irregular surface of revolution. Therefore, it was also necessary to determine the ideal place of the axis of rotation. The shifted planetocentric coordinates unambiguously determine the points on the surface of revolution. To minimize the error of this approximation, a modified Downhill Simplex method was utilized. For the mapping of the surface of revolution, an equal-area map projection is developed, which resembles the shape of the comet.

Kulcsszavak: üstökös térképek, szabálytalan formájú égitestek térképezése Keywords: comet maps, mapping of the celestial bodies with irregular shapes

\section{Bevezetés}

Napjainkban a folyamatosan fejlôdô ûrtechnológiák segítségével egyre több égitestet ismerünk meg, amelyek felszínének vizsgálata a térképezést is magába foglalja. Az újonnan megismert égitestek között változatos formákkal találkozunk. Az amorf kisbolygó és üstökösök felszíne nem közelíthetố jól a szokásos gömb vagy forgási ellipszoid alapfelülettel. Ebben a cikkben ezeknek az égitesteknek a térképezési lehetôségét vizsgáljuk. Célunk egy olyan munkafolyamat kidolgozása, amely tetszóleges amorf égitestre alkalmazható.

$\mathrm{Az}$ általunk kiválasztott égitest, melyen a térképi referenciarendszerek kidolgozását végezzük, a 67P/ Csurjumov-Geraszimenko üstökös. Az üstököst 1969-ben fedezte fel Kljim Ivanovics Csurjumov egy ûrfelvételen, melyet Szvetlana Ivanovna Geraszimenko készített (Guliyev 2019). Az üstökös 2014-ben került a figyelem középpontjába, amikor a Rosetta-program keretében egy egység sikeresen landolt a felszínén. Az üstököst érdekes alakja miatt választottuk. Az égitest egy kisebb és egy nagyobb részbôl áll, melyek méretei $2,6 \times 2,3 \times 1,8 \mathrm{~km}$ és $4,1 \times 3,3 \times 1,8 \mathrm{~km}$. Az üstökös felszínének áthajlásai miatt nem lehet a pontokat a megszokott planetocentrikus szélességgel és hosszúsággal egyértelmúen leírni és a szokásos módon síkba vetíteni (ESA 2020).

\section{Égitest-térképezés korábban}

Ahogy a Föld esetében meghatározhatunk geocentrikus és földrajzi koordinátákat, úgy más égitesteken is ezeknek megfelelốn léteznek planetocentrikus és planetografikus koordináták (1. ábra). Általában más bolygók felszínének az ábrázolására manapság egyre inkább a planetocentrikus rendszert használjuk (Hargitai et al. 2017), hiszen ez úgy ábrázolja az adott égitestet, mintha egy külsố megfigyelô rendszerből néznénk. Ebből a nézetbôl tudták megfigyelni az egyes bolygók forgását is, és az egyes rendszerekben ettôl függốen határozták meg a hosszúsági fokok előjelét is.
A kisbolygók és üstökösök térképezésére már az 1980-as évektôl kezdve háromtengelyú ellipszoidot használnak alapfelületnek. Az elsố ilyen közelítést a Mars egyik holdjára, a Phobosra dolgozták ki (Bugajevszkij 1987).

Néhány példa a háromtengelyú ellipszoid alapfelület alkalmazására az elmúlt évtizedekból: Bugajevszkij (1987) egy szögtartó hengervetületet hozott létre a Phobos ábrázolására. Ez a földi Mercator-vetület általánosítása, a pólusok ábrázolására nem alkalmas ezért ott egy meridiánban hossztartó síkvetülettel egészítették ki (Hargitai et al. 2017) (2. a ábra). A Phobos mintájára az Erosznak is elkészítették a háromtengelyú ellipszoidra illesztését

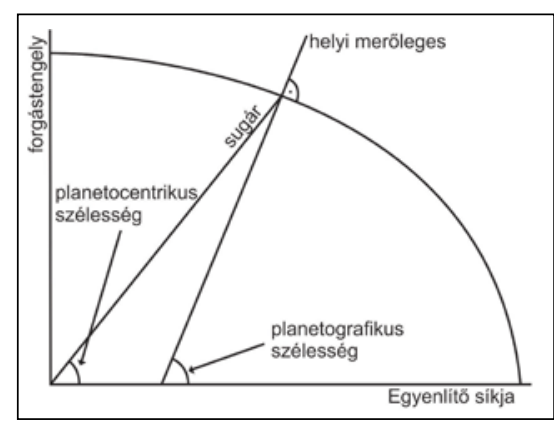

1. ábra. Planetocentrikus és planetografikus szélesség meghatározása 

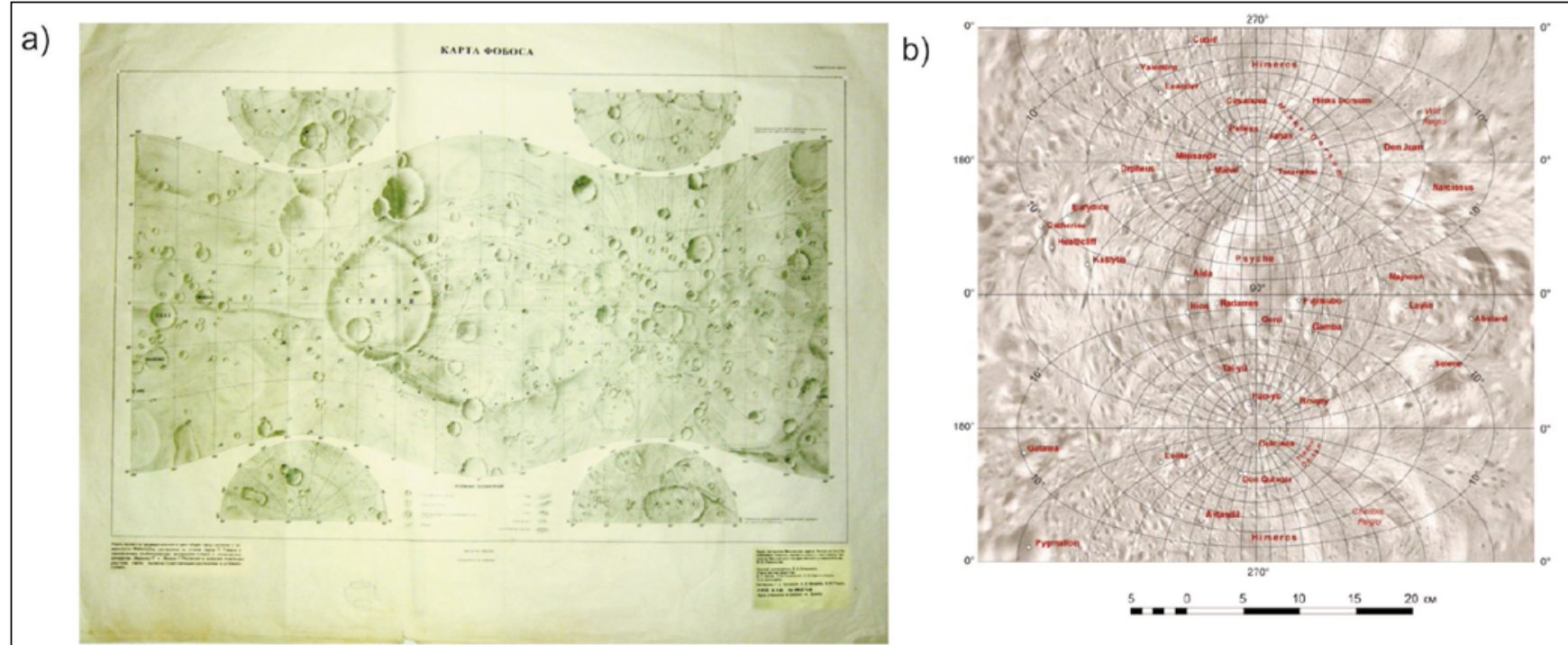

c)

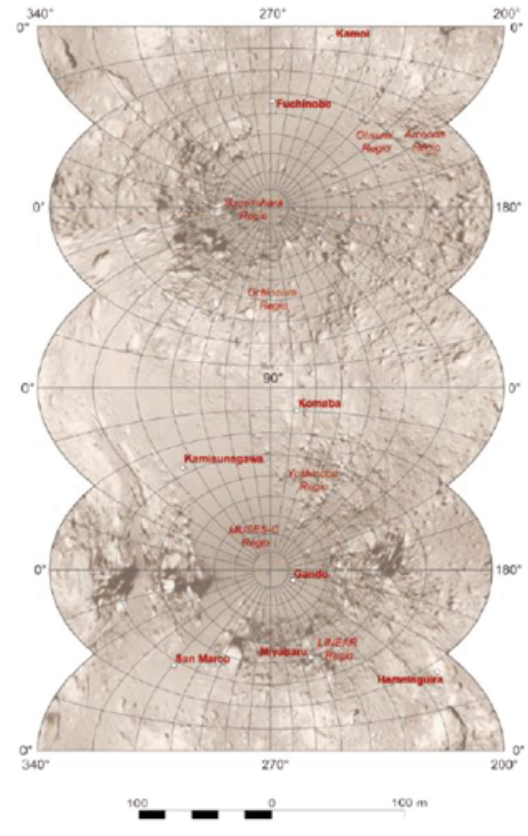

d)

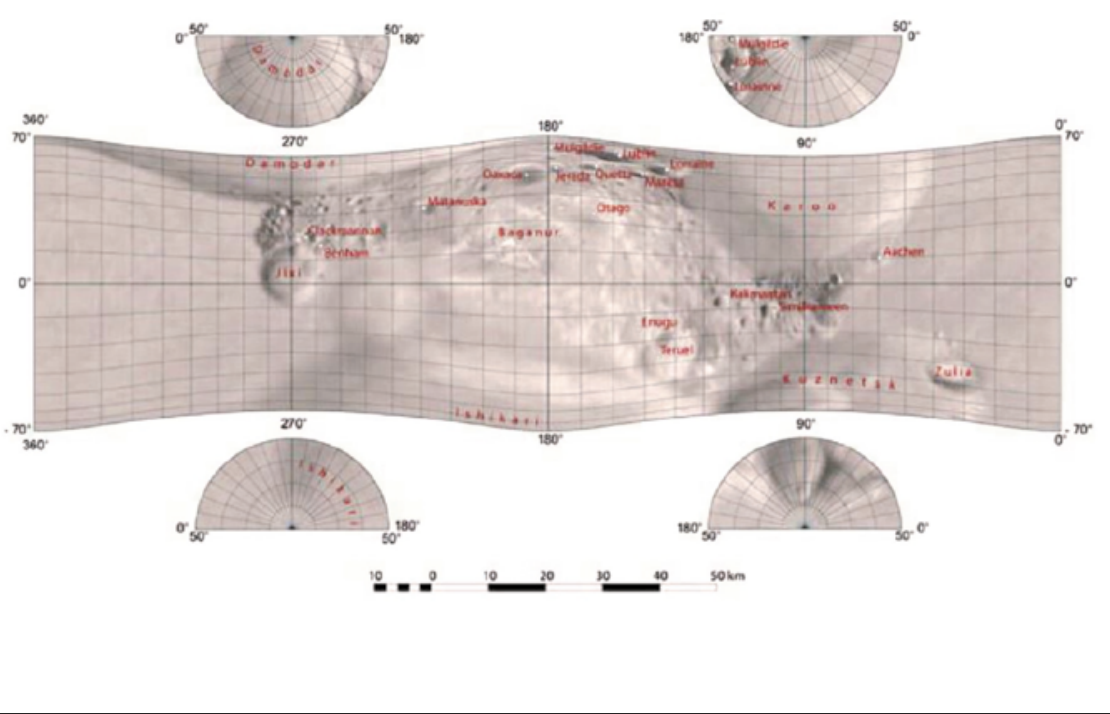

2. ábra. Példák a háromtengelyú alapfelületü térképekre: a) Phobosz, b) Erosz, c) Itokawa, d) Mathild A képek forrásai: Bolshakov et al.(1988); Nircov et al. (2014, 2015)

és síkba vetítését. Az Erosz esetében a térképi megjelenítéshez egy meridiánban hossztartó hengervetületet készítettek (Nircov et al. 2012) (2. b ábra). Az Itokawa aszteroida esetében egy Jacobi-féle szögtartó vetületet alkalmaztak. Ez a vetület analóg a teljes Földre alkalmazott Gauss-Krüger vetülettel (Nircov et al. 2014) (2. c ábra). A Mathild aszteroidára területtartó sík- és hengervetületeket készítettek el. A pólusok ábrázolására használták a sík, az Egyenlítő környékére a hengervetületet (Nircov et al. 2015) (2. d ábra). Az általunk kiválasztott égitest nem közelíthetô jól egyetlen háromtengelyú ellipszoiddal. Orosz kartográfusok kidolgozták ugyan az égitest térképét (Nircov et al. 2018), melyet két elforgatott háromtengelyú ellipszoiddal közelítettek, ráadásul a két ellipszoid közötti átmeneti részt egy külön gömbbel közelítették. Ez a térkép nem ábrázolta egyben az üstökös egészét, hanem a két ellipszoidot külön-külön képezték le. Ezek miatt túl sok szakadás lépett föl, az üstököst 11 külön térképen tudták ábrázolni.

\section{A modellezés lehetóségei}

Az alapfelület modellezésére azért van szükség, hogy az alakjának egyértelmú matematikai leírást tudjunk adni. Az általunk vizsgált égitest közelíthetô egy általános alakú, sima forgásfelülettel, melynek Z' forgástengelye mint koordinátatengely az X, Y, Z térbeli planetocentrikus koordinátarendszer egyik tengelyével sem esik egybe. A forgásfelülettel történô közelítés egyszerúbb képleteket eredményez, mint egy általános, zárt, sima felülettel történô közelítés; ráadásul a geodéziából ismert összefüggések (pl. a Clairaut- és a Meusniertétel) bármilyen sima forgásfelületen érvényesek maradnak. Egy szabálytalan forgástestet többfajta modellezési lehetôséggel lehet leírni. Számunkra ezek közül egy olyan módszerre van 
szükség, ahol egyértelmúen meg tudjuk határozni a forgásfelület egy meridiánjának futását valamilyen koordináta-rendszerben.

\section{Merôleges vetítés a forgástengelyre}

Ennél a modellezési lehetôségnél egy $r\left(Z^{\prime}\right)$ függvénnyel írható le a felület. A függvény meghatározza a $Z^{\prime}$ forgástengely egy adott pontjában a forgásfelület távolságát a forgástengelytôl. (3. ábra) az $r\left(Z^{\prime}\right)$ függvényre feltételeket szabhatunk a $\pm Z^{\prime}{ }_{0}$ pontban, azaz az égitest két pólusánál:

$$
\begin{gathered}
\boldsymbol{r}\left(\boldsymbol{Z}^{\prime}\right)=\boldsymbol{r}\left(-\boldsymbol{Z}_{{ }_{0}}{ }^{\prime}=0\right. \\
\frac{-\boldsymbol{d r}\left(\boldsymbol{Z}_{0}^{\prime}\right)}{d \boldsymbol{Z}^{\prime}}=\frac{\boldsymbol{d r}\left(-\boldsymbol{Z}_{{ }_{0}}\right)}{d \boldsymbol{Z}^{\prime}}=\infty
\end{gathered}
$$

E feltételeket kielégíti, ha $r\left(Z^{\prime}\right)$ az alábbi alakú:

$$
\boldsymbol{r}\left(\boldsymbol{Z}^{\prime}\right)=\sqrt{\left(\boldsymbol{Z}^{\prime}-\boldsymbol{Z}_{\left.{ }_{0}{ }_{0}\right)\left(\boldsymbol{Z}^{\prime}+\boldsymbol{Z}^{\prime}{ }_{0}\right)}\right.} \cdot \boldsymbol{p}\left(\boldsymbol{Z}^{\prime}\right)
$$

ahol $p\left(Z^{\prime}\right)$ tetszóleges pontossággal közelíthetô Taylor-sorfejtéssel:

$$
p\left(Z^{\prime}\right) \approx \zeta_{0}+\zeta_{1} \cdot Z^{\prime}+\zeta_{2} \cdot Z^{\prime 2}+\ldots
$$

Nem lehet tetszóleges alakú a test, hiszen egy $Z^{\prime}$ értékhez egyetlen $r$ érték tartozhat a függvény egyértelmú hozzárendelése miatt (felkiáltójellel jelölt pont a 3. ábrán).

\section{Fourier-sorfejtésen alapuló modellezés}

Ez a módszer is alkalmas arra, hogy egy 3D-s forgástest felszínét leírjuk. A felszín leírására egy paraméteres függvényt alkalmazunk (4. a ábra). A $\varrho\left(\beta^{*}\right)$ meghatározza a felszín minden pontjának a távolságát a középponttól a $\beta^{*}$ planetocentrikus pólustávolság függvényében egy polárkoordinátarendszerben. Mivel $\varrho\left(\beta^{*}\right)=\varrho\left(-\beta^{*}\right)$ és $\varrho\left(\beta^{*}+2 \pi\right)=\varrho\left(\beta^{*}\right)$, ezért a függvényünk páros és $2 \pi$ periódusú. Megállapítható továbbá, hogy a

$$
0 \leq \int_{0}^{2 \pi} \mathrm{d} \beta \leq 2 \pi e_{\max }^{2}
$$

integrál egy perióduson belül véges, így tehát $\varrho$ kifejezhetô Fourier-sorfej téssel:

$$
\begin{aligned}
& \varrho\left(\beta^{*}\right) \approx a_{0}+b_{1} \cdot \sin \beta^{*}+ \\
& +a_{1} \cdot \cos \beta^{*}+b_{2} \cdot \sin \left(2 \beta^{*}\right)+ \\
& +a_{2} \cdot \cos \left(2 \beta^{*}\right)+b_{3} \cdot \sin \left(3 \beta^{*}\right)+ \\
& +a_{3} \cdot \cos \left(3 \beta^{*}\right)+\ldots
\end{aligned}
$$

A szinuszfüggvény nem páros, ezért ezek a tagok kiesnek a sorfejtésból. Így az függvényünk csak koszinuszos együtthatóktól függ.

$e^{\left(\beta^{*}\right) \approx a_{0}+a_{1} \cdot \cos \beta^{*}+a_{2} \cdot \cos \left(2 \beta^{*}\right)+a_{3} \cdot \cos \left(3 \beta^{*}\right)+\ldots}$

Ez a módszer sem alkalmas minden felület leírására. A nagyon amorf felszínú testek esetében ennek az alkalmazása során azt tapasztaljuk, hogy a középpontból kiinduló vezérsugár több helyen metszheti a felületet (Shen et al. 2009) (4. b ábra).

\section{A felület paraméterezése a meridián ívhosszával}

A harmadik módszer adja talán a legjobban vissza a felszín alakját; ebben az esetben a forgásfelületet a meridián ívhosszával paraméterezzük. A meridián futását $r(i)$ és $Z^{\prime}(i)$ függvényekkel tudjuk leírni (5. ábra). Az r $(i)$ megmutatja az adott $i$ ívhosszhoz tartozó, forgástengelytôl mért távolságot, míg a $Z^{\prime}(i)$ az adott ívhosszhoz tartozó függóleges koordinátát határozza meg. Mivel az $i$ paraméter a pólustól mért görbe távolság, a differenciálgeometriai összefüggések miatt $Z^{\prime}(i)$ és $r(i)$ deriváltjainak teljesíteni kell a következó egyenletet:

$$
\sqrt{\left(\frac{d Z^{\prime}}{d i}\right)^{2}+\left(\frac{d r}{d i}\right)^{2}}=1
$$

Ilyen függvénypárokat nem lehet egyszerúen fölírni.

\section{Az alapfelület meghatározása}

A munkafolyamat során az általunk kiválasztott égitest 3D-s modelljét használtuk fel. A modellt az Európai Úrügynökség (ESA 2019) honlapjáról töltöttük le. A modell kétféle adattípust tartalmaz: az egyik „v" kezdőbetúkkel felsorolja az egyes csúcspontoknak az $X, Y, Z$ koordinátáit, a másik „f” kezdôbetûkkel olyan számhármasokat tartalmaz, amelyek megmutatják az egyes háromszög alakú oldallapokat képezô csúcspontok sorszámait.

Elôször egy olyan középpontot keresünk, ahonnan lehetôség szerint az amorf formájú üstökös felszínének minden pontjára rálátunk. Az elsố feladatunk ezen középpont és a forgástengely ideális helyzetének meghatározása volt. Az így meghatározott, eltolt planetocentrikus szélesség a lehetôségekhez mérten egyértelmúen jellemezni tudja a forgásfelület parallelköreit. A munkafolyamat során a számításokat Python-környezetben végeztük.

A modellt tartalmazó .obj (Wavefront OBJect) fájl beolvasása után az $X, Y, Z$ koordinátákra egy térbeli elforgatási mátrixot ( $B A$ mátrix) alkalmaztunk, amely az A és B mátrixok által reprezentált elforgatások egymás utáni alkalmazása. Az elforgatott térbeli derékszögú koordinátákat vesszôs X', Y' és Z' betûkkel jelöljük figyelembe véve még egy $Z^{\prime}$ irányú $Z_{\mathrm{t}}$ nagyságú eltolást is.

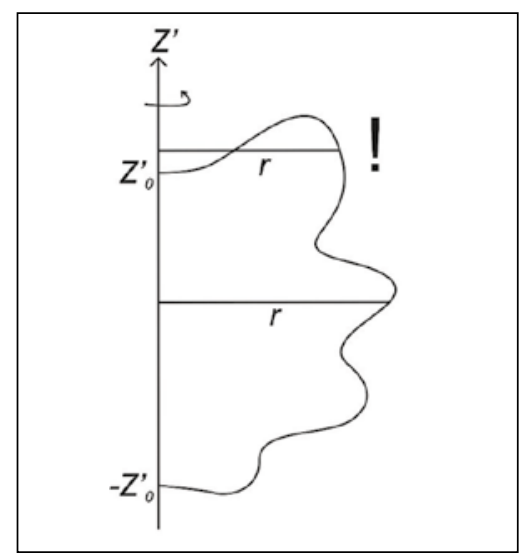

3. ábra. Merôleges vetítés a forgástengelyre

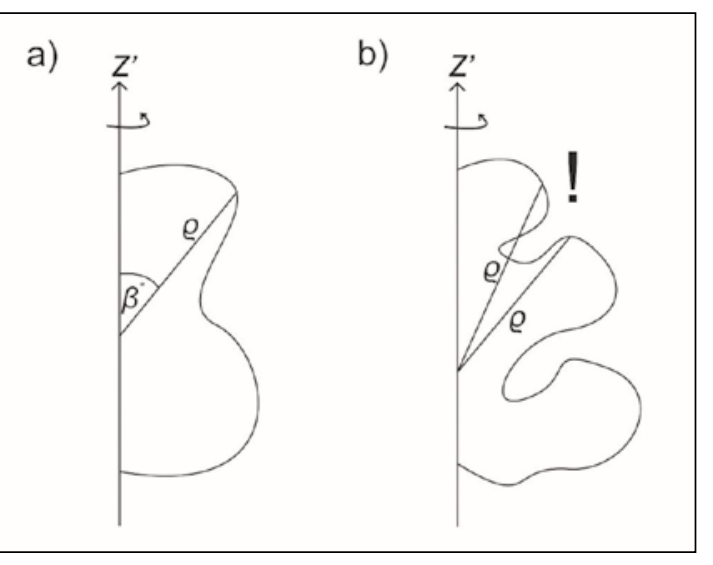

4. ábra. Fourier-sorfejtésen alapuló modellezés a) paraméterek b) kivételes eset

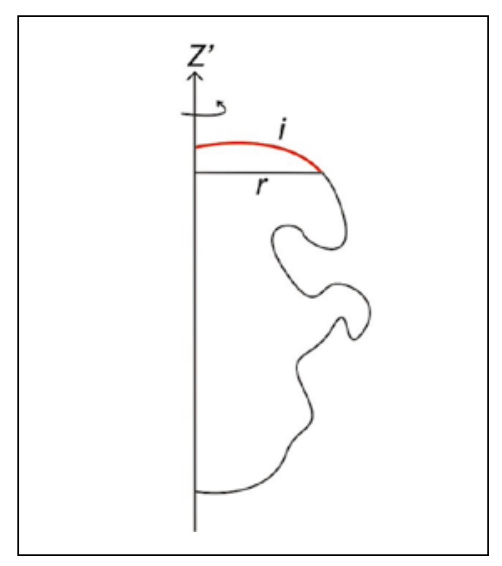

5. ábra. Egy meridián forgástengelytôl való távolsága az ivhossz függvényében. 
1. elforgatás: $A=\left(\begin{array}{ccc}\cos \lambda_{0} & \sin \lambda_{0} & 0 \\ -\sin \lambda_{0} & \cos \lambda_{0} & 0 \\ 0 & 0 & 1\end{array}\right)$

2. elforgatás: $B=\left(\begin{array}{ccc}\cos \beta_{0} & 0 & -\sin \beta_{0} \\ 0 & 1 & 0 \\ \sin \beta_{0} & 0 & \cos \beta_{0}\end{array}\right)$

A két elforgatás együtt:

$B A=\left(\begin{array}{ccc}\cos \beta_{0} \cos \lambda_{0} & \cos \beta_{0} \sin \lambda_{0} & -\sin \beta_{0} \\ -\sin \lambda_{0} & \cos \lambda_{0} & 0 \\ \sin \beta_{0} \cos \lambda_{0} & \sin \beta_{0} \sin \lambda_{0} & \cos \beta_{0}\end{array}\right)$

Az eredeti $X, Y, Z$ és az elforgatott $X$, Y',Z' koordináta-rendszer között tehát az alábbi összefüggés áll fönn:

$$
\left(\begin{array}{l}
X^{\prime} \\
Y^{\prime} \\
Z^{\prime}
\end{array}\right)=B A\left(\begin{array}{c}
X \\
Y \\
Z
\end{array}\right)+\left(\begin{array}{c}
0 \\
0 \\
Z^{\prime}{ }_{t}
\end{array}\right)
$$

A forgásfelülettel való közelítésnek hibája is van, hiszen az üstökös valójában nem tökéletes forgástest alakú. Ennek a hibának a vizsgálata és csökkentése céljából a következôket végeztük el: a pontokat szélesség szerint kategóriákba soroltuk. A kategóriába sorolás osztásközeit a program különbözô futtatásai során átállítottuk, a következố intervallumszélességeket próbáltuk ki: $1^{\circ}, 2^{\circ}, 5^{\circ}, 10^{\circ}$ (1. táblázat). Ha egy test tökéletes forgásfelület, akkor a középpontban vett bármely nyílásszögú kúp egy olyan kört metsz ki, melynek pontjai az eltolt középponttól azonos távolságra vannak. Az ettôl vett eltérés a pontok eltolt középpontból vett távolságának szórásnégyzete, melyet minden szélességkategóriában külön-külön kiszámoltunk. Az így meghatározott hibaérték azt is jelzi, ha a kúp több helyen metszi a felületünket. Tapasztalataink szerint az 5 fokos felbontás már elég részletes képet nyújtott.

A forgásfelület modellezésére a Fourier-soros közelítést választottuk. Annak érdekében, hogy a vezérsugár lehetóleg csak egyszer messe a felületet, a vezérsugarak kezdôpontját nem az égitest tömegközéppontjában, hanem a $Z^{\prime}$ forgástengely mentén eltolva vettük fel. A koordináta-rendszer elforgatási szögei $\left(\beta_{0}, \lambda_{0}\right)$ mellett az eltolás optimális $Z_{\mathrm{t}}$ értékét is kerestük.

A hiba minimalizálása céljából a downhill simplex módszer módosított változatát (Kaczmarczyk é. n.) alkalmaztuk (6. ábra). Legmegfelelőbbnek az bizonyult, hogy elôször az elforgatási és eltolási értékeket optimalizáltuk, az itt kapott eredményeket az

1 táblázat.
\begin{tabular}{|c|c|c|c|c|}
\hline $\begin{array}{c}\text { Felbontás } \\
\text { (fok) }\end{array}$ & $\lambda_{0}$ (radián) & $\beta_{0}$ (radián) & $Z_{\mathrm{t}}^{\prime}(\mathrm{km})$ & $\begin{array}{c}\text { Összeegzett négy- } \\
\text { zetes hiba }\left(\mathrm{km}^{2}\right)\end{array}$ \\
\hline $1^{\circ}$ & 1,4461 & $-0,3655$ & 0,4434 & 12,1390 \\
\hline $2^{\circ}$ & 1,4463 & $-0,3625$ & 0,4303 & 6,0851 \\
\hline $5^{\circ}$ & 1,4483 & $-0,3458$ & 0,4357 & 2,4673 \\
\hline $10^{\circ}$ & 1,4530 & $-0,3478$ & 0,4564 & 1,2796 \\
\hline
\end{tabular}

Fourier-soros közelítés együtthatóinak keresése során kezdőértékeknek alkalmaztuk, majd ezt is optimalizáltuk. Ez a heurisztikus eljárás a függvény lokális minimumhelyeit keresi meg (Nelder-Mead 1965).

Amennyiben nem találjuk meg a függvény minimumhelyét a szimplex transzformációk (tükrözés, megnyújtás, összehúzódás) segítségével, a szimplex a legkisebb pont körül minden irányból összezsugorodik. Ez utóbbi a program lefutása során többször is megtörténhet, de erre oda kell figyelnünk, mert előfordulhat, hogy ezért nem a minimumhely közelében lesz a szimplex mérete kisebb a kilépési feltételnél. Ebben az esetben téves eredményt is kaphatunk, különösen, ha a szimplex túl sokszor zsugorodik össze. Ennek elkerülése érdekében a módszernek a Kaczmarczyk által kidolgozott módosítását alkalmaztuk.
Ennek lényege, hogy az összezsugorodás elkerülése érdekében további pontokat is kipróbál a legrosszabb és legjobb pontot összekötô egyenes mentén (6.ábra). Különböző kezdőértékekre kipróbálva az eljárást, három lokális minimum-értéket találtunk. Annak érdekében, hogy a program lehetôség szerint globális minimumba találjon, egy kiegészítô függvényt tettünk bele, amely a megtalált lokális minimumot veszi új kezdô értéknek, és ezt használva új eljárásba kezd. Ha a soron következô optimalizálás eredménye hibahatáron belül megegyezik az elốzố eljárás eredményével, az eljárás kilép, egyébként megint lefut. Ilyenkor a különbözô kezdôértékekre kapott eredmények közül a legjobbat választjuk eredményül. Ezzel az eljárás lassabb lett, de megbízhatóbb eredményt kaptunk. Az eredményben megkapott értékek radiánban vannak, és

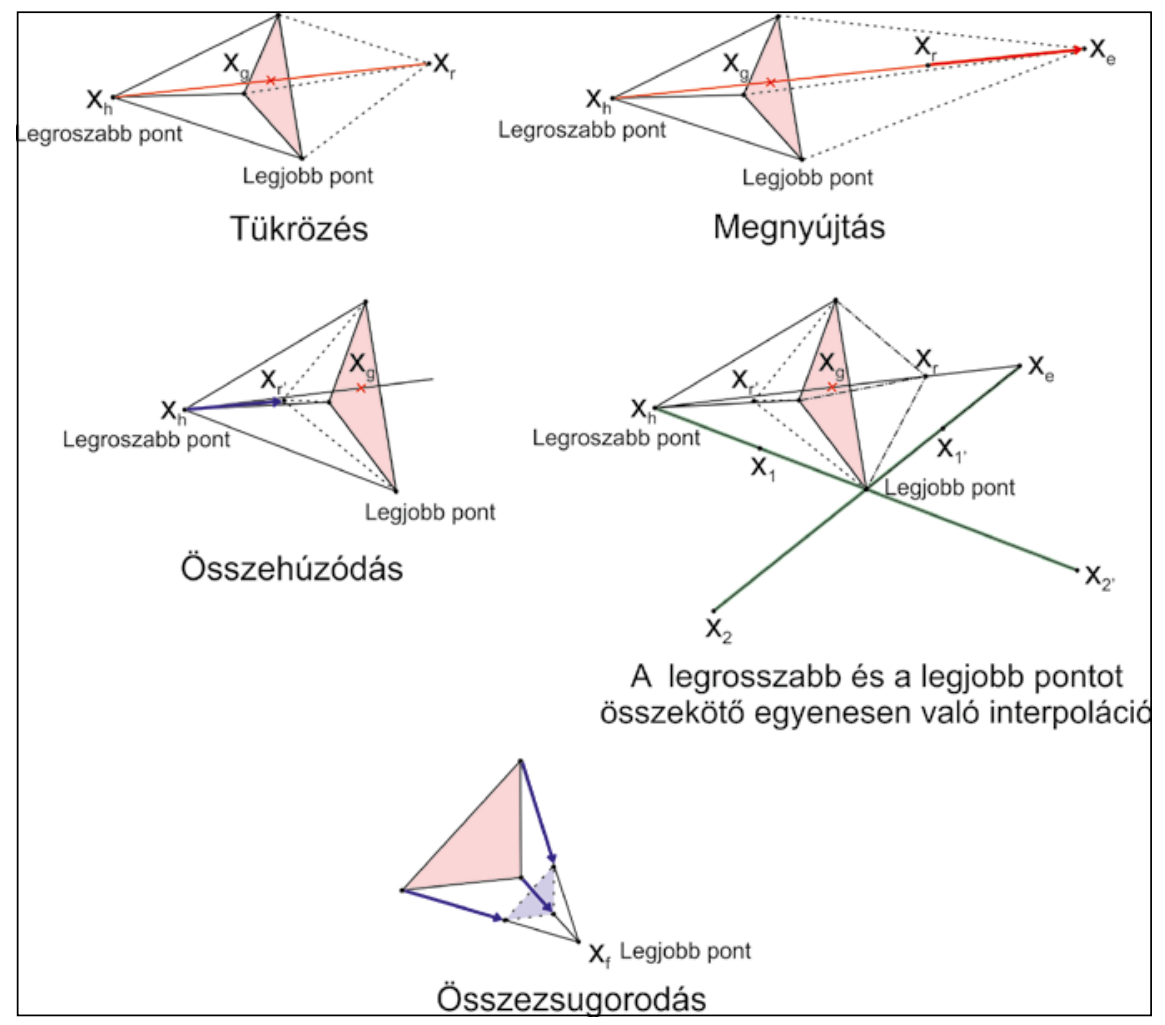

6. ábra. A módosított downhill simplex lehetséges lépései 
adnak egy kezdőértéket az alapfelület leírásához, és megadják, hogy mennyi a segédpólus hosszúsága és pólustávolsága, amelyek egyértelmúen meghatározzák az ideális forgástengely irányát. Ezen kívül azt is megkapjuk, hogy a középpont mennyivel tolódik el és milyen irányban. Ezt követôen határoztuk meg az alapfelület Fourier-soros közelítésének együtthatóit ugyanezen módszerrel.

$$
\begin{aligned}
\varrho\left(\beta^{*}\right) \approx a_{0}+a_{1} \cdot \cos \beta^{*}+ \\
\\
+a_{2} \cdot \cos \left(2 \beta^{*}\right)+ \\
+a_{3} \cdot \cos \left(3 \beta^{*}\right)+\ldots
\end{aligned}
$$

A sorfejtés során keressük azokat az a értékeket, amelyeket behelyettesítve egy olyan $\hat{\varrho}$ értéket kapunk, hogy az $E$ átlagos hiba a lehetô legkisebb legyen.

$$
E=\sqrt{\frac{\sum(\varrho-\hat{\varrho})^{2}}{n}}
$$

ahol a $\varrho$ az üstökös felszínének távolsága az eltolt középponttól, $\hat{\varrho}$ a Fourier-sor által számított vezérsugár és az $n$ a csomópontok száma.

A Fourier-sorfejtés során több együtthatószámot is megvizsgáltunk. Az ideális ebben az esetben nyolc

2. táblázat Fourier-sorfejtés során kapott értékek (a szögértékek radiánban, a távolságértékek kilométerben értendôk)

\begin{tabular}{|c|c|}
\hline$\beta_{0}$ & 1,466083671689564 \\
\hline$\lambda_{0}$ & $-0,30772564761801646$ \\
\hline$Z_{0}^{\prime}$ & 0,17384711818701806 \\
\hline $\mathrm{a}_{1}$ & 1,710468611681618 \\
\hline $\mathrm{a}_{2}$ & $-0,03012094884439919$ \\
\hline $\mathrm{a}_{3}$ & 0,38531560422326494 \\
\hline $\mathrm{a}_{4}$ & 0,3341331398169681 \\
\hline $\mathrm{a}_{5}$ & $-0,11475961687674407$ \\
\hline $\mathrm{a}_{6}$ & 0,01849124993537946 \\
\hline $\mathrm{a}_{7}$ & $-0,1296687215243982$ \\
\hline $\mathrm{a}_{8}$ & $-0,009696089235291569$ \\
\hline
\end{tabular}
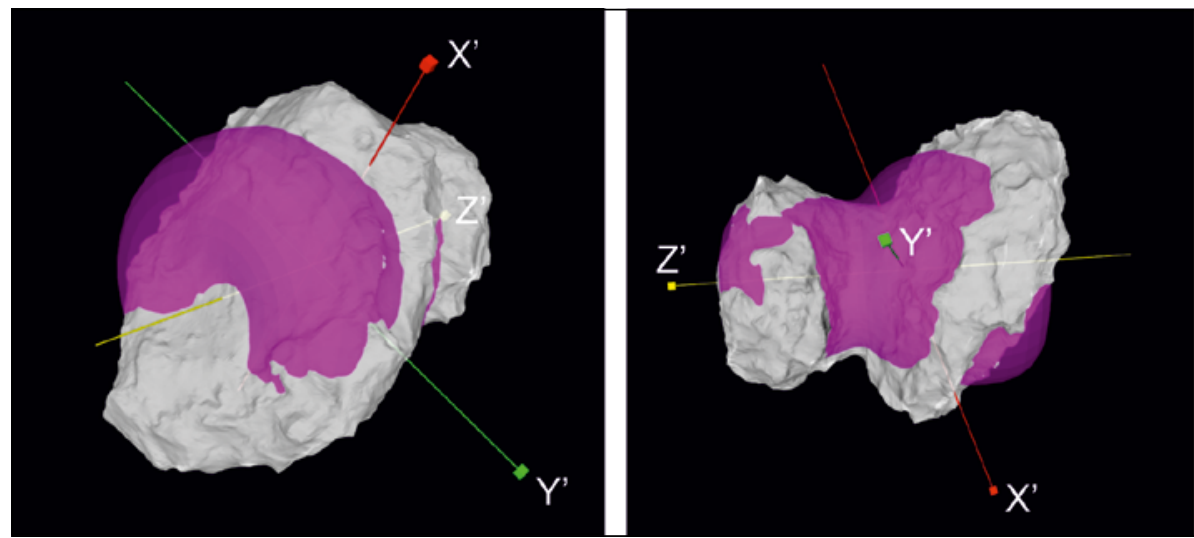

7. ábra. Az új alapfelület és az üstökös viszonya a középmeridiánban és a parallelkörök tartó is. A parallelkörök képei párhuzamos egyenesek. A gömb alapfelülettel definiált vetületben a meridiánok képei szinuszívesek, ezt az általánosítás során azonban el kellett engednünk. Ez a vetület az általánosítást követően alkalmasnak bizonyult arra, hogy a térkép átvetítésekor, a kapott eredmény utaljon az égitest amorf formájára. Ez azért szerencsés, mert így a vetület kielégíti az ún. hasonlósági elvet (Klinghammer 2015).

Az általánosítás első lépéseként fogalmazzuk meg a képzetes hengervetületek általános egyenleteit:

$$
\begin{gathered}
X=x\left(\varphi^{*}, \lambda^{*}\right) \\
Y=y\left(\varphi^{*}\right)
\end{gathered}
$$

ahol $\varphi^{*}$ és $\lambda^{*}$ az elforgatott és forgástengely mentén eltolt középpontból értelmezett planetocentrikus szélességet és hosszúságot jelölik.

Az általunk meghatározott alapfelületnek először a középmeridiánban való hossztartását vizsgáltuk. A felületet felosztjuk pici sávokra, melyek paraméterezésére az $\underline{\mathbf{r}}$ (a parallelkör sugara) és a $Z^{\prime}$ (a parallelkör síkjának az eltolt középpontjától való távolsága) változókat használjuk. Az eltolt középpont, $r$ és $Z^{\prime}$ egy derékszögú háromszöget alkotnak, melynek átfogója $\varrho$

$$
\begin{aligned}
& Z^{\prime}=\varrho \cdot \sin \varphi^{*} \\
& r=\varrho \cdot \cos \varphi^{*}
\end{aligned}
$$

A szélesség kicsiny megváltozásához tartozó ívhossz meghatározható a Pitagórasz-tétel segítségével (8.ábra):

$(\Delta i)^{2}=\Delta^{2} i=\Delta^{2} Z^{\prime}+\Delta^{2} r=$

$=\Delta^{2} \varrho \cdot \cos ^{2} \varphi^{*}+\varrho^{2} \cdot \sin ^{2} \varphi^{*}+\Delta^{2} \varrho \cdot \sin ^{2} \varphi^{*}+\varrho^{2} \cdot \cos ^{2} \varphi^{*}=$ $=\varrho^{2}+\Delta^{2} \varrho$

$$
\Delta i=\sqrt{e^{2}+\left(\frac{\Delta \varrho}{\Delta \varphi^{*}}\right)^{2}}
$$

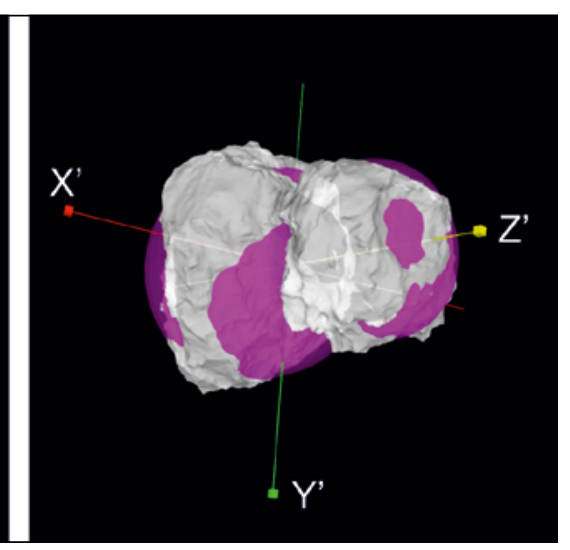
hossza.

A függóleges koordináta a fenti kis ivhosszak összegzéséből származik, amely a felosztást minden határon túl finomítva a következô integrálba megy át:

$$
y=\int_{0}^{\varphi} \sqrt{e^{2}+\left(\frac{d e}{d \varphi^{*}}\right)^{2}} \mathrm{~d} \varphi^{*}
$$

Ezt az integrált nem lehetséges analitikus módszerekkel kifejteni, ezért becsléséhez numerikus módszerek (pl. Gauss-kvadratúra) szükséges.

A parallelkörök hossztartásának eléréséhez egy picike parallelkör-darabot vettünk, melynek hossza $r \Delta \lambda^{*}$. A vízszintes $\mathrm{x}$ koordináta ezen picike parallelívdarabok összege, amely a felosztást minden határon túl finomítva, egy integrálba megy át.

$$
x=\int_{0}^{\lambda^{*}} r d \lambda^{*}=\varrho \cdot \cos \varphi \cdot \lambda^{*}
$$




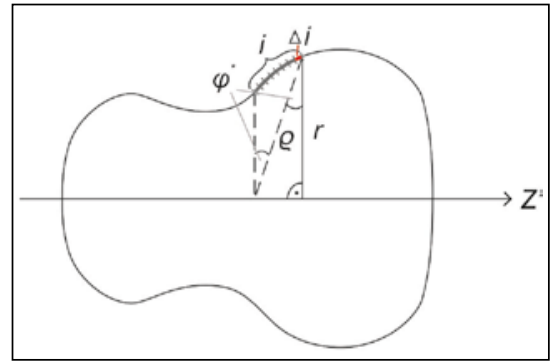

8. ábra. Ívhossz meghatározása

Mercator-Sanson vetületi egyenletei általános forgásfelületre tehát:

$$
\begin{aligned}
& y=\int_{0}^{\varphi} \sqrt{e^{2}+\left(\frac{d e}{d \varphi^{*}}\right)^{2}} \cdot d \varphi^{*} \\
& x=r \cdot \lambda^{*}=\varrho \cdot \cos \varphi^{*} \cdot \lambda^{*}
\end{aligned}
$$

A vetület tulajdonságai közül eredetileg csak a középmeridiánban és a parallelkörökben vett hossztartást szerettük volna megórizni. Végül nem csak ezeket sikerült megtartani, hanem a területtartást is sikerült megőrizni. Ennek bizonyítását egy paralelogramma területének a leképezésével tudjuk elvégezni.

Az eredeti elemi kis foktrapéz területe közelíthető egy elemi kis téglalappal (9. ábra).

$\Delta T=\Delta i \cdot r \Delta \lambda^{*}=\sqrt{e^{2}+\left(\frac{d \varrho}{d \varphi}\right)^{2}} \cdot \Delta \varphi^{*} \cdot \varrho \cdot \cos \varphi^{*} \cdot \Delta \lambda^{*}$

Leképezett infinitezimális paralelogramma területe (10. ábra):

$\Delta T^{\prime}=$ alap $*$ magasság $=\Delta x \cdot \Delta y=$

$=e \cdot \cos \varphi^{*} \cdot \Delta \lambda^{*} \cdot \sqrt{e^{2}+\left(\frac{d \varrho}{d \varphi^{*}}\right)^{2}} \cdot \Delta \varphi$

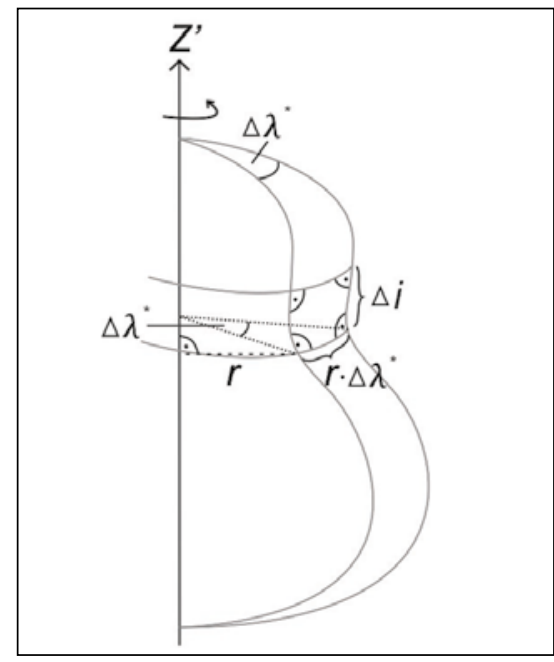

9. ábra. Elemi kis foktrapéz területe

Mivel az eredeti $\Delta T$ és $\Delta T^{\prime}$ leképezett elemi felületek felszíne a szélességtôl és hosszúságtól függetlenül megegyezik, ezért belátható, hogy a vetület területtartó.

Annak ellenére, hogy a vetületnek három tulajdonságát is sikerült megôrizni, a meridiánok szinuszíves képének megtartása nem volt lehetséges az általánosítás során.

\section{A vetület alkalmazása}

Az így kidolgozott vetület bemutatására egy az üstökösrôl készült geomorfológiai térképet (Birch et al. 2017) vetítettünk át (11. ábra). Az eredeti ábrához tartozó térkép (A. jelû) négyzetes

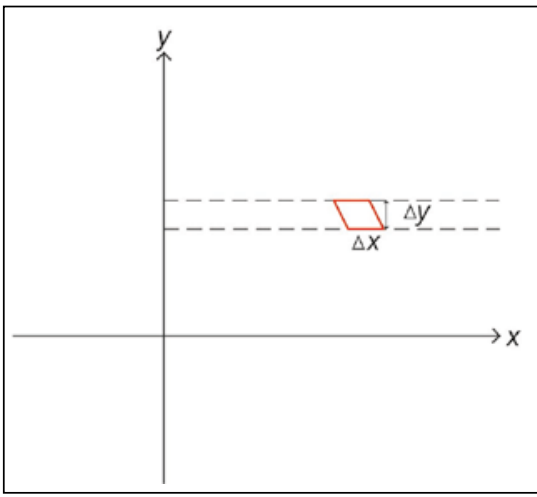

10. ábra. Elemi kis paralelogramma területe

hengervetületben készült, és az egyszerúbb értelmezhetôség érdekében mellékeltek hozzá különbözô nézetből 3D-s perspektív ábrákat is. Ezen a térképen nem értelmezhetók egyértelmúen az üstökösnek azon pontjai, amelyek az áthajlásoknál vannak. Az általunk meghatározott egzakt vetületi egyenlet segítségével egy olyan térképet hoztunk létre, amely egyértelmúen meg tudja határozni a felszín pontjait a referencia rendszer alapján, valamint utal az üstökös amorf alakjára is (B hasáb).

Megrajzoltuk a fokhálózat képét is az új vetületben (12.ábra). Azábrán látható, hogy a régi gömbi planetocentrikus fokháló (kék) átvetítésekor nem mindenhol simák a fokhálózati vonalak. Ennek az az oka, hogy az üstökös amorf alakja miatt a gömb és a mi alapfelületünk közötti dátumtranszformáció az áthajlásoknál nem teljesen egyértelmú.

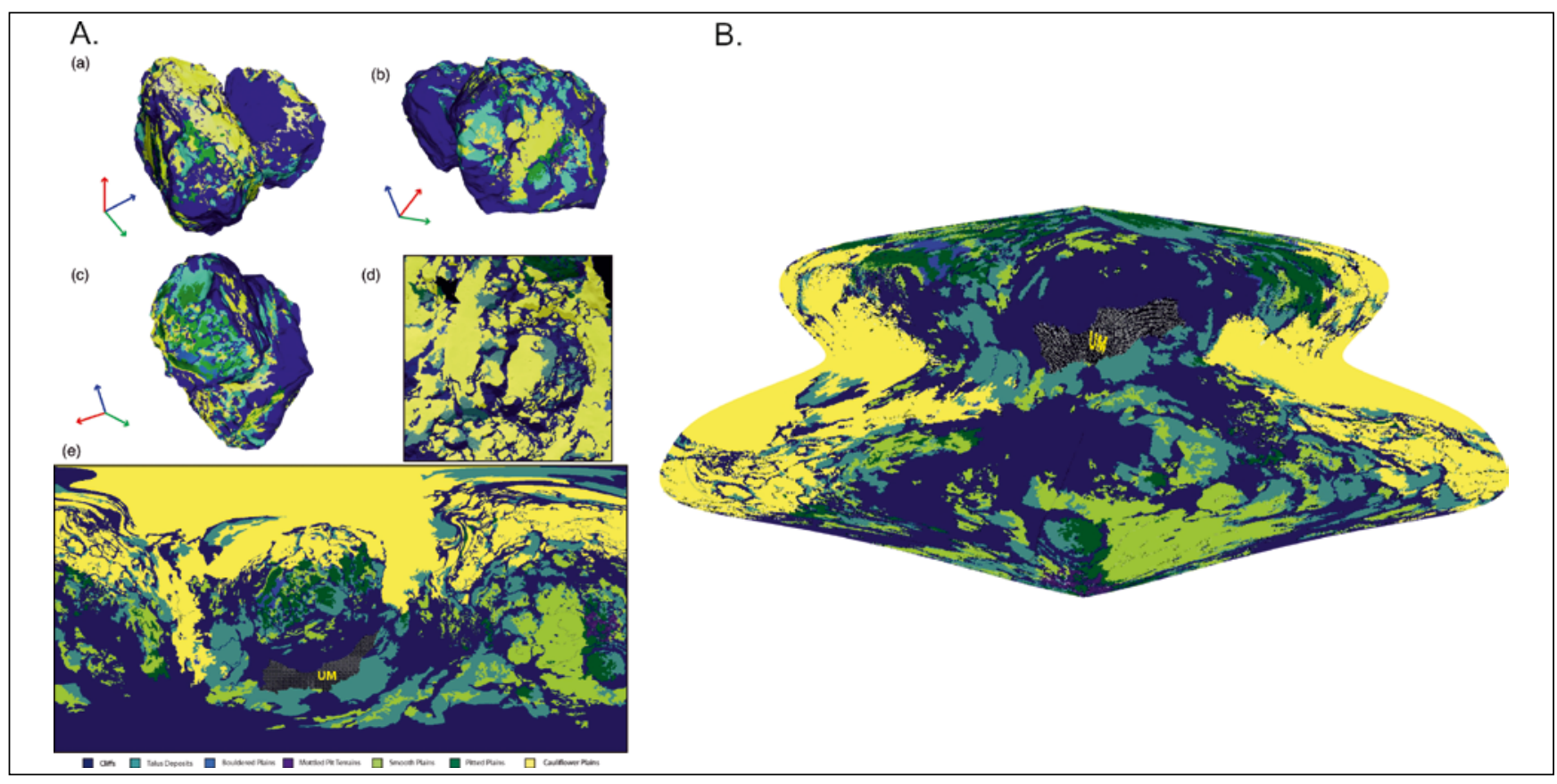

11. ábra. Geomorfológiai térkép A) négyzetes hengervetületben, perspektív ábrákkal, B) az általunk meghatározott új vetületben 


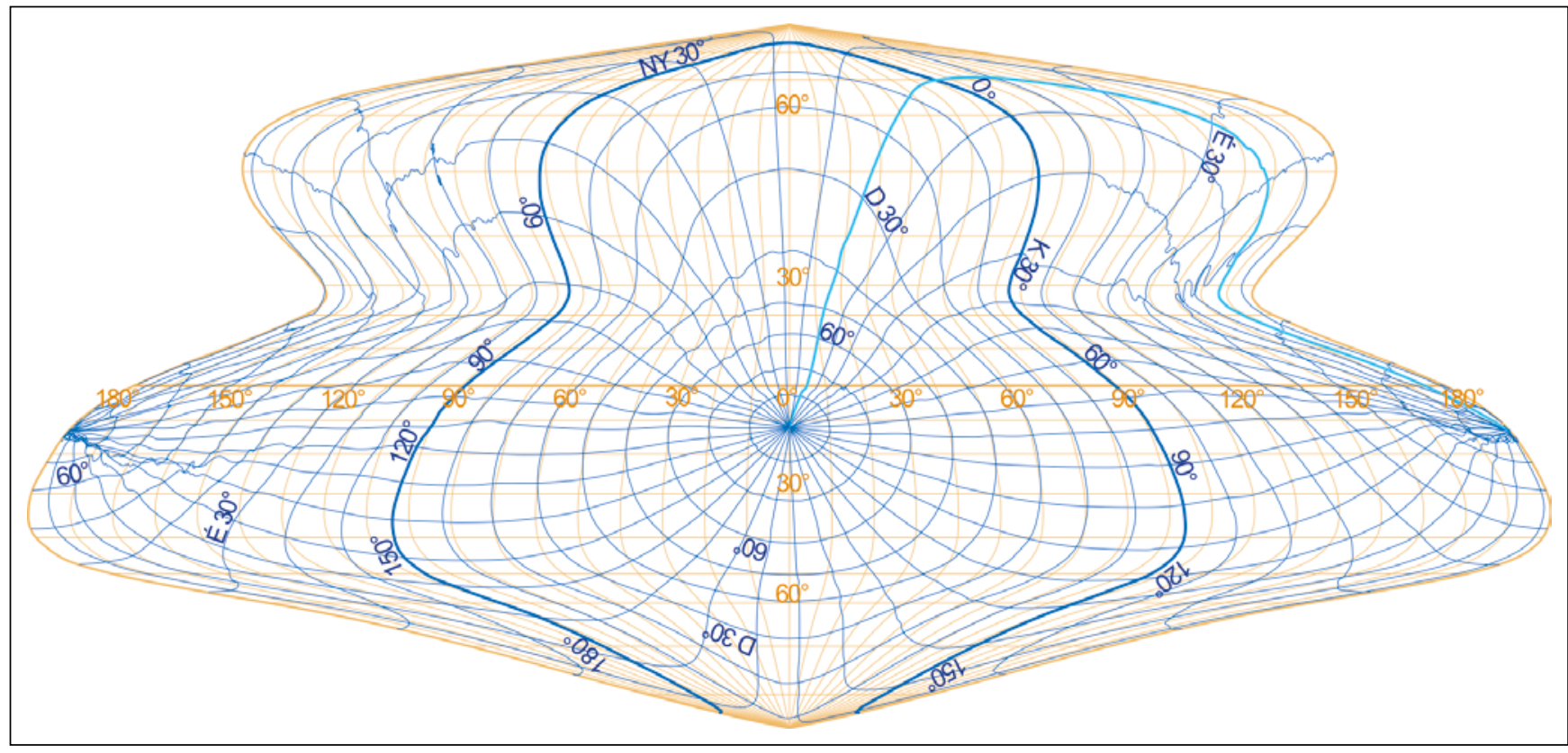

12. ábra. Kék: az eredeti, gömbi planetocentrikus fokhálózat átvetítése az új rendszerbe, narancs: a szabálytalan forgástest alapfelületen értelmezett segédfokhálózat 1:75000 méretarányban

\section{Eredmény}

Az üstökös alapfelületének meghatározásával és a vetületi egyenletek felírásával elkészült az égitest síkba vetítése. Az általunk meghatározott módszertan segítségével bármely forgástest alakú égitest térképi ábrázolása megvalósítható. Az alapfelület leírását úgy határoztuk meg, hogy egy segédszélességhez egy vezérsugár tartozhat. Ez bizonyos mértékig kezelni tudja felület áthajlásait, szemben a gömb alapfelülettel. Ennek a módszernek a segítségével egyetlen térképen tudjuk ábrázolni az amorf formájú égitesteket. Az így kapott térkép valamelyest emlékeztet az alapfelület alakjára is, szemben a korábban alkalmazott négyzetes hengervetülettel. A szakirodalmi kutatásaink alapján eddig senki nem alkalmazott még ilyen fajta ábrázolásmódot a hasonló esetekben.

\section{Irodalom}

Birch, S., Tang, Y., Hayes, A., Kirk, R., Bodewits, D., Campins, H., ... Vincent, J.-B. (2017). Geomorphology of comet 67P/Churyumov-Gerasimenko. Monthly Notices of the Royal Astronomical Society, 469, old.: 50-67.

DOI: $10.1093 /$ mnras/stx1096

Bugajevszkij, L. (1987). K voproszu o polucsenyii izometricseszkih koordinat i ravnougolnoj cilindricseszkoj projekcii trjohosznogo ellipszoida. Geogyezija $i$ aerofotoszjomka, 4, 79-90.
ESA. (2019). Letöltés dátuma: 2019. június 24, forrás: http://open.esa.int/ rosetta-3d-model/

ESA. (2020. január 10). Forrás: https://sci.esa. int/web/rosetta/-/55295-getting-to-knowrosetta-s-comet

Guliyev, R. (2019). On the orbital evolution and origin of comet $67 \mathrm{P} / \mathrm{Churyumov}-$ Gerasimenko. In Science Without Borders (4. kötet, old.: 259). Innsbruck.

Hargitai, H., Wang, J., Stooke,, P. Karachevtseva, I., Kereszturi, Á., \& Gede, M. (2017). Map Projections in Planetary Cartography. In Choosing a Map Projection (old.: 177-202). Cham: Springer. DOI: $10.1007 / 978-3-319-51835-0-7$

Kaczmarczyk, G. (é.n.). Downhill Simplex method for many ( 20) dimensions. Institute of Theoretical Physics and Astrophysics. University of Gdansk: Wita Stwosza 57.

Klinghammer, I. (2015). A kartográfia alapjairól: a térképvetületek kezdetei. Geodézia és Kartográfia, LXVII(7-8), 14-19. DOI: $10.30921 / \mathrm{GK} \cdot 67.2015 .4 .3$

Nelder, J., \& Mead, R. (1965). A Simplex Method for Function Minimization. The Computer Journal, 7(4), old.: 308-313. DOI: $10.1093 / \mathrm{comjnl} / 7.4 .308$

Nircov, M., Flejsz, M., \& Boriszov, M. (2012). Kartografirovanyije aszteroida 433 Erosz $\mathrm{v}$ ravnopromezsutocsnih vdolj meridianov cilinricseszkoj i azimutalnoj projekcijah trjohosznogo ellipszoida. Geogyezija $i$ aerofotoszjomka, 1, 54-61.

Nircov, M., Flejsz, M., Boriszov, M., \& Stook, P. (2014). Jacobi conformal projection of the triaxial ellipsoid: new projection for mapping of small celestial bodies. In Cartography from Pole to Pole (old.: 235246). Berlin, Heidelberg: Springer. DOI: $10.1007 / 978-3-642-32618-917$

Nircov, M., Flejsz, M., Boriszov, M., \& Stooke, P. (2015). Equal-area projections of the triaxial ellipsoid: first time derivation and implementation of cylindrical and azimuthal projections for small solar system bodies. The Cartographic Journal, 52(2), old.: 114-124. DOI: 10.1080/00087041.2015.1119471

Nircov, M., Flejsz, M., Nyikolajeva, D., \& Orendarcsuk, A. (2018). Kartografirovanyije nyebesznih tyel szo szdvojennoj figuroj $\mathrm{v}$ projekcijah trjohosznogo ellipszoida na primere binarnogo jadra kometi $67 \mathrm{P} /$ Csurjumova-Geraszimenko. Geogyezija $i$ aerofotoszjomka, 62(5), old.: 514-523. DOI: 10.30533/0536-101X-2018-62-5-514-523

Shen, L., Farid, H., \& McPeek, M. A (2009). Modeling three-dimensional morphological structures using spherical harmonics. Evolution: International Journal of Organic Evolution, 63(4), 1003-1016.

DOI: $\underline{10.1111 / j .1558-5646.2008 .00557 . x}$

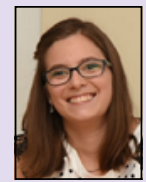

Takáts Tünde MSc egyetemi hallgató

ELTE Térképtudományi és Geoinformatikai Tanszék tunde.takats@gmail.com

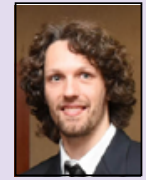

Dr. Kerkovits Krisztián adjunktus

ELTE Térképtudományi és Geoinformatikai Tanszék kerkovits@map.elte.hu 